\title{
Hubungan Frekuensi Makan dan Pola Istirahat dengan Produksi ASI pada Ibu Nifas
}

\author{
Christina Nur Widayati, Yuwanti, Rizki Sahara \\ Email: christinawidayati83@gmail.com \\ S1 Keperawatan Universitas An Nuur, Indonesia \\ Jl. Gajahmada No.7 Purwodadi, Grobogan \\ Telp/Fax (0292) 426455
}

\begin{abstract}
Abstrak
ASI merupakan suatu emulsi lemak dalam larutan protein, laktase dan garam-garam organik yang disekresi oleh kedua belah kelenjar payudara ibu, sebagai makanan utama bagi bayi. Ibu nifas yang memproduksi ASI sedikit akan mengganggu kecukupan kebutuhan bayi dalam masa pertumbuhan dan perkembangannya. Tujuan penelitian ini, yaitu untuk mengetahui hubungan antara frekuensi makan dan pola istirahat dengan produksi ASI ibu selama masa nifas di desa Sambung Grobogan. Metode penelitian ini menggunakan metode analitik dengan pendekatan cross sectional. Sampel dalam penelitian berjumlah 31 orang. Uji analitik untuk hipotesa penelitian menggunakan uji Chi Square. Hasil penelitian ini diketahui bahwa ibu yang mengkonsumsi makanan dengan frekuensi sering sebanyak 38,7 \%, dan ibu yang memiliki pola istirahat baik memiliki produksi ASI cukup sebanyak 14,3\%. Hasil analisis dengan menggunakan Chi Square dengan $\alpha=0,05$ pada frekuensi makan dengan produksi ASI ditemukan nilai $p$ value $=0,092$, sedangkan pola istirahat dengan produksi ASI diketahui nilai $\mathrm{p}$ value $=0,241$. Penelitian ini dapat disimpulkan bahwa frekuensi makan tidak berhubungan dengan produksi ASI pada ibu, dan pada pola istirahat juga tidak berhubungan dengan produksi ASI pada ibu selama masa nifas.
\end{abstract}

Kata Kunci: frekuensi makan; pola istirahat; produksi asi.

\begin{abstract}
Breast milk is an emulsion of fat in a solution of protein, lactase and organic salts secreted by the two sides of the mother's breast glands, as the main food for the baby. Post-partum mothers who produce little breast milk will interfere with the adequacy of the baby's needs during their growth and development. The purpose of this study was to determine the relationship between eating frequency and resting patterns with mother's milk production during the postpartum period in the village of Kontak Grobogan. This research method using analytical method with cross sectional approach. The sample in this study amounted to 31 people. The analytical test for the research hypothesis used the Chi Square test. The results of this study show that mothers who consume food frequently are $38.7 \%$, and mothers who have good resting patterns have sufficient milk production as much as $14.3 \%$. The results of the analysis using Chi Square with $\alpha=0.05$ on the frequency of eating with breast milk production found a $\mathrm{p}$ value $=0.092$, while the resting pattern with breast milk production is known to have a $\mathrm{p}$ value $=0.241$. It can be concluded from this study that the frequency of eating is not related to the production of breast milk in the mother, and the resting pattern is also not related to the production of breast milk in the mother during the postpartum period.
\end{abstract}

Keywords: feeding frequency; resting patterns; breast milk production. 
Jurnal Kebidanan Harapan Ibu Pekalongan

\section{Pendahuluan}

ASI (Air Susu Ibu) merupakan sumber makanan yang memiliki berbagai zat gizi penting yang di butuhkan dalam masa pertumbuhan dan perkembangan bayi. ASI sebagai makanan yang terbaik dapat diberikan pada bayi sejak dilahirkan. Komposisi ASI yang terdiri dari protein, karbohidrat, lemak, mineral, air dan vitamin sangat sesuai dengan pertumbuhan dan perkembangan bayi yang berubah sesuai dengan kebutuhan dan usianya. ASI memiliki zat perlindungan yang dapat menghindarkan bayi dari berbagai penyakit. Kandungan ASI dapat memberikan perlindungan secara aktif dan pasif, selain itu pemberian ASI juga menguntungkan bagi ibu yang dapat membantu mempercepat pemulihan diri pada dari proses persalinannya.virus, jamur, atau parasit. ${ }^{(1)}$

Profil Kesehatan Indonesia tahun 2015 mencatat bahwa cakupan pemberian ASI ekslusif pada bayi usia kurang dari enam bulan sebesar $55,7 \%$ dengan target nasional sebesar $39 \%$, namun demikian data menunjukkan masih ada wilayah provinsi yang cakupan pemberian ASI dibawah target seperti Sulawesi Utara sebesar $36,3^{\% .(2)}$, sedangkan tahun 2018 cakupan bayi yang mendapatkan ASI ekslusif sebesar $67,74 \%$ dari target rensta tahun 2018 sebesar $47 \%$, cakupan tertinggi yaitu Provinsi Jawa Barat ( 90,79\%), cakupan tertendah pada provinsi Gorontalo (30,71\%), sedangkan di provinsi Jawa Tengah mencapai 45,21 \% dimana angka ini masih dibawah target nasional. ${ }^{(3)}$.Penelitian menunjukkan bahwa ada faktor- faktor yang mempengaruhi dalam pemberian ASI esklusif pada bayi seperti usia ibu, status pekerjaan, urutan kelahiran bayi, dukungan petugas kesehatan, dan faktor lain seperti status pekerjaan pada ibu. ${ }^{(4)}$, selain itu faktor lain yang mendukung praktik pemberian ASI juga berasal dari pendidikan ibu, pengetahuan, perilaku serta faktor lingkungan yang mempengaruhi pemberian $\mathrm{ASI}^{(5)}$. Pemberian ASI pada bayi yang seharusnya diberikan secara ekslusif pada praktiknya juga banyak dipengaruhi oleh aspek seperti sikap yang tidak setuju dengan ASI ekslusif, motivasi dalam memberikan ASI kurang, adanya payudara bengkak, informasi tentang ASI kurang, adanya orang terdekat subjek yang kurang mendukung, dan program PP-ASI ekslusif yang bukan prioritas puskesmas. ${ }^{(6)}$

Berdasarkan penelitian yang telah dilakukan sebelumnya tentang faktor yang mempengaruhi dalam pemberian ASI baik yang mendukung maupun yang menghabat dalam pemberian ASI maka pada penelitian ini dimaksudkan untuk mengetahui hubungan antara frekuensi makan dan pola istirahat pada ibu terhadap peningkatan produktsi ASI pada masa Nifas.

\section{Metode penelitian}

Penelitian ini merupakan penelitian analitik yang bertujuan untuk mengetahui hubungan antara frekuensi makan dan pola istrirahat pada ibu terhadap peningkatan produksi ASI pada masa nifas yang dilakukan di desa Sambung, Grobogan. Desain penelitian ini menggunakan desain Cross Sectional. Sampel dalam penelitian ini berjumlah 31 orang yang diambil dari total sampling. Analisis data menggunakan uji Chi Square untuk mengetahui hubungan antara variabel bebas dan variabel terikat. Variabel bebas pada penelitian ini 
adalah frekuensi makan dan pola istirahat, sedangkan variabel terikat penelitian ini yaitu produksi ASI ibu.

\section{Hasil dan pembahasan}

Hasil penelitian hubungan frekuensi makan dan pola istirahat dengan produksi ASI pada ibu pada masa nifas diketahui bahwa Distribusi frekuensi yang ditemukan dalam penelitian ini diketahui umur responden terbanyak pada rentang 20 - 35 tahun sejumlah $74,2 \%$ orang, dan usia kurang dari 20 tahun sebanyak 25,8 \%. Responden pada penelitian ini juga menunjukkan jumlah terbanyak yaitu sebagai petani sejumlah $45,2 \%$, sedangkan responden yang tidak bekerja sejumlah 22,6\%. Responden dengan frekuensi makan terbanyak yaitu sering sejumlah $58,1 \%$, dan responden dengan frekuensi makan kadang - kadang sejumlah 41, $9 \%$. Responden yang memiliki pola istritahat baik sejumlah $74,2 \%$, sedangkan responden dengan pola istrirahat buruk sejumlah $28,2 \%$.

Tabel 3.1. Distribusi Frekuensi Karakteristik Responden.

\begin{tabular}{lccc}
\hline Kategori & & Jumlah & $\%$ \\
\hline Umur & $<20$ & 8 & 25,8 \\
& $20-35$ & 23 & 74,2 \\
& $>35$ & 0 & 0 \\
\hline Pekerjaan & & \\
Tidak bekerja & 7 & 22,6 \\
Petani & 14 & 45,2 \\
Swasta & 10 & 32,3 \\
\hline Frekuensi Makan & & \\
Kadang - Kadang & 13 & 41,9 \\
Sering & 18 & 58,1 \\
& & \\
\hline Pola Istirahat & & \\
Baik & 23 & 74,2 \\
Buruk & 8 & 28,2 \\
\hline
\end{tabular}

Tabel 3.2 Hubungan Frekuensi Makan dengan Produksi ASI pada Ibu nifas

\begin{tabular}{|c|c|c|c|c|}
\hline \multirow{2}{*}{$\begin{array}{c}\text { Frekuensi } \\
\text { makan }\end{array}$} & \multicolumn{2}{|c|}{ Produksi ASI } & \multirow{2}{*}{ Total } & \multirow{2}{*}{$\begin{array}{c}\mathrm{X}^{2} \\
\text { hitung }\end{array}$} \\
\hline & Cukup & Baik & & \\
\hline $\begin{array}{l}\text { Kadang } \\
\text { kadang }\end{array}$ & 1 & 12 & 13 & \\
\hline $\begin{array}{l}\% \text { dari } \\
\text { total }\end{array}$ & $\begin{array}{c}(3.2 \% \\
)\end{array}$ & $\begin{array}{l}(38.7 \\
\%)\end{array}$ & $\begin{array}{l}(41.9 \\
\%)\end{array}$ & \\
\hline Sering & 6 & 12 & 18 & 2,839 \\
\hline $\begin{array}{l}\% \text { dari } \\
\text { total }\end{array}$ & $\begin{array}{l}(19.4 \\
\%)\end{array}$ & $\begin{array}{l}(38.7 \\
\%)\end{array}$ & $\begin{array}{l}(58.1 \\
\%)\end{array}$ & \\
\hline Jumlah & 7 & 24 & 31 & \\
\hline $\begin{array}{l}\% \text { dari } \\
\text { total }\end{array}$ & $\begin{array}{l}(22.6 \\
\%)\end{array}$ & $(77.4 \%)$ & $\begin{array}{l}(100 \\
\%)\end{array}$ & \\
\hline
\end{tabular}

Tabel 3.3 Hubungan pola makan dengan Produksi ASI pada ibu Nifas

\begin{tabular}{|c|c|c|c|c|c|}
\hline \multirow{2}{*}{$\begin{array}{c}\text { Pola } \\
\text { Istirahat }\end{array}$} & \multicolumn{2}{|c|}{ Produksi ASI } & \multirow{2}{*}{ Total } & \multirow{2}{*}{$\begin{array}{c}\mathrm{X}^{2} \\
\text { hitung }\end{array}$} & \multirow{2}{*}{$\begin{array}{c}p \\
\text { value }\end{array}$} \\
\hline & Cukup & Baik & & & \\
\hline Buruk & 3 & 5 & 8 & \multirow{6}{*}{1.373} & \multirow{6}{*}{0,241} \\
\hline $\begin{array}{l}\% \text { dari } \\
\text { total }\end{array}$ & $(9.7 \%)$ & $\begin{array}{c}(16.1 \\
\%)\end{array}$ & $\begin{array}{l}(25.8 \\
\%)\end{array}$ & & \\
\hline Baik & 4 & 19 & 23 & & \\
\hline $\begin{array}{l}\% \text { dari } \\
\text { total }\end{array}$ & $\begin{array}{c}(12.9 \\
\%)\end{array}$ & $\begin{array}{c}(61.3 \\
\%)\end{array}$ & $\begin{array}{c}(74,2 \\
\%)\end{array}$ & & \\
\hline Jumlah & 7 & 24 & 31 & & \\
\hline $\begin{array}{l}\% \text { dari } \\
\text { total }\end{array}$ & $\begin{array}{c}(22.6 \\
\%)\end{array}$ & $(77.4 \%)$ & $\begin{array}{l}(100 \\
\%)\end{array}$ & & \\
\hline
\end{tabular}

\section{Frekuensi Makan dengan Produksi ASI}

ASI (Air Susu Ibu) yaitu air susu yang dihasilkan oleh ibu dan mengandung berbagai sumber zat gizi yang diperlukan oleh bayi dalam memenuhi kebutuhan pertumbuhan dan perkembangannya. ASI diberikan kepada bayi tanpa tambahan cairan lain seperti air, madu ataupun makanan lainnya 
selama 6 bulan. Kandungan nutrisi dalam ASI selain lengkap juga memiliki efek lain yaitu sebagai perlindungan penyakit infeksi seperti otitis media akut, diare dan penyakit saluran pernafasan. ${ }^{(7)}$.

Hasil penelitian frekuensi makan dengan produksi ASI ibu menunjukkan bahwa responden dengan frekuensi makan kadangkadang namun memiliki produksi ASI cukup sejumlah 1 orang (3,2\%), responden dengan frekuensi makan sering dengan produksi ASI cukup sejumlah 7 orang ( $22,6 \%)$, sedangkan responden dengan frekuensi makan kadang -kadang dan produksi ASI baik sejumlah 12 orang ( 38,7\%), sedangkan responden dengan frekuensi makan sering dan produksi ASI baik sejumlah 18 orang $(58,1 \%)$. Hasil analisis dengan menggunakan Chi Square dengan nilai $\mathrm{X}^{2}$ hitung menunjukkan 2,839 , sedangkan nilai $\mathrm{p}=0.092$, hasil ini dapat disimpulkan bahwa dengan nilai $\alpha=0,05$ berarti frekuensi makan tidak berhubungan dengan produksi ASI pada ibu selama masa nifas.

Hasil penelitian ini berbeda dengan penelitian yang dilakukan oleh Deswita (2018) dimana nutrisi ibu mempengaruhi Produksi $\mathrm{ASI}^{(8)}$, dan penelitian ini juga berbeda dengan hasil penelitian yang dilakukan oleh Sanima (2017) yang mencatat bahwa pola makan berhubungan dengan produksi $\mathrm{ASI}^{(9)}$.

Perbedaan hasil penelitian ini dapat saja terjadi dikarenakan pada penelitian ini hanya sebatas frekuensi makan saja yang dihitung sedangkan jumlah nutrisi atau nilai gizi harian yang dikonsumsi oleh responden tidak dihitung. Gizi seimbang atau nutrisi yang dikonsumsi ibu selama masa menyusui juga erat kaitannya dengan produksi ASI, karena itu pemenuhuan gizi yang baik dan seimbang juga mempengaruhi status gizi ibu dan juga tumbuh kembang bayi, oleh sebab itu selama masa nifas ibu menyusui membutuhkan zat gizi lebih banyak dibandingkan dengan pada saat tidak menyusui dan masa kehamilan, dengan berbagai ragam pangan dan porsi yang sesuai. Kebutuhan gizi selama menyusui diperlukan tambahan $500 \mathrm{kalori} / \mathrm{hari}$ selama 6 bulan pertama menyusui dengan jumlah total energi selama menyusui menjadi 2400 kkal perhari yang digunakan untuk memproduksi ASI dan aktifitas ibu sendiri selama menyusui.

Penelitian menunjukkan bahwa meskipun status gizi yang dihitung dari IMB dan LILA ibu tidak berkorelasi dengan kecupukan ASI namun penelitian yang sama mencatat bahwa kadar hemoglobin pada ibu berkorelasi dengan kecupukan ASI, hal ini berarti bahwa gizi buruk pada ibu akan mempengaruhi kecukupan ASI karena tubuh membutuhkan gizi cukup untuk memproduksi ASI yang cukup pada ibu untuk memproduksi $\mathrm{ASI}^{(10)}$. Penelitian lain mencatat bahwa pemberian makan pralakteral juga berhubungan dengan produksi ASI, dimana responden yang tidak memberikan makanan praktalteral ternyata produksi ASInya masih cukup, sedangkan ibu yang memberikan makanan praklateral ternyata mampu memproduksi ASI Cukup. ${ }^{(11)}$.

Berdasarkan hasil penelitian dapat disimpulkan bahwa pola makan pada ibu tidak berhubungan dengan produksi ASI, tetapi untuk memproduksi ASI pada ibu selama masa nifas dibutuhkan zat gizi yang beragam selama menyusui antara lain karbohidrat, protein, lemak, vitamin dan mineral, serta kebutuhan cairan yang cukup, sehingga akan memperbaiki produksi ASI. 


\section{Hubungan Pola istirahat dengan produksi ASI}

Istirahat sebagai kebutuhan dasar dibutuhkan oleh semua orang, dan untuk dapat berfungsi secara optimal, maka setiap orang memerlukan istirahat dan tidur. Fisiologi terjadinya tidur melibatkan perubahan fungsi sel saraf otak yang aktif dan dinamis. Beberapa bagian otak yang terlibat dalam tidur-bangun adalah Reticular Activating System (RAS), nukleus raphe dan formasi retikular kaudal, jadi selama tidur, otak kita tidak tidur. RAS dibagian atas batang otak diyakini memiliki sel-sel khusus yang dapat mempertahankan kewaspadaan dan kesadaran, memberi stimulis visual, pendengaran, nyeri, dan sensori raba, serta emosi dan proses pikir. Pada saat sadar, RAS melepaskan katekolamin dan saat tidur terjadi pelepasan serum serotonin. Sedangkan Ascending Reticular Activating System (ARAS), adalah suatu proyeksi serabut difus yang menuju bagian area diforebrain. Nuklei retikular talamus juga masuk dalam ARAS, yang juga mengirimkan serabut difus kesemua area dikorteks serebri. Tahapan tidur dapat dibedakan menjadi dua yaitu Non Rapied Eye Movement (NREM) yaitu masa transisi dan bangun (sadar) ketidur, serta berkaitan dengan relaksasi otot dan aktivitas psikologis yang minimal. Rapied Eye Movement (REM) yaitu masa transisi dan sulit untuk dibangunkan, pada bebrapa orang terkadang merasakan ingin bangun, tapi badannya tidak bisa untuk digerakkan.

Hasil penelitian menunjukkan bahwa responden yang memiliki pola istirahat buruk dan memproduksi ASI cukup sejumlah 3 orang ( $9,7 \%)$, sedangkan responden yang memiliki pola istirahat buruk dan produksi ASI baik sejumlah 5 orang $(15,1 \%)$. Responden dengan pola istirahat baik dan produksi ASI cukup sejumlah 4 orang ( $12,9 \%)$, sedangkan responden yang memiliki pola istirahat baik dan produksi ASI baik sejumlah 23 orang $(74,2 \%)$. Hasil analisis menggunakan Chi Square didapatkan bahwa nilai $\mathrm{X}^{2}$ hitung adalah 1,373 , dan nilai $p$ value $=0,241$ dengan $\alpha=$ 0,05 maka disimpulkan bahwa pola istirahat tidak berhubungan dengan produksi ASI pada ibu selama masa nifas. Hasil penelitian ini berbeda dengan penelitian yang dilakukan olehDeswita (2018) dimana pola isirahat berpengaruh pada produksi ASI dan responden yang memiliki pola istiharat cukup memiliki 6,545 kali lebih baik memproduksi ASI dibandingkan responden yang pola istirahat tidak cukup $^{(8)}$. Perbedaan hasil pada penelitian ini dengan penelitian yang lainnya dapat saja disebabkan oleh karakteristik ibu atau responden yang berbeda. Selama masa nifas ibu membutuhkan waktu istirahat rerata 6-8 jam perhari, namun demikian bukan hanya pemenuhan banyaknya waktu yang dibutuhkan tetapi juga berkaitan dengan kualitas istirahat yang dilakukan oleh ibu. Fungsi istirahat yaitu untuk menjaga keseimbangan baik mental, emosional, maupun kesehatan, menjaga kondisi organ organ tubuh seperti paru-paru, kardiovaskuler, sistem endokrin pulih setelah sepanjang hari digunakan sedemikain rupa. Faktor - faktor yang dapat mempengaruhi istirahat antara lain adanya penyakit, keletihan aktifitas fisik, stres psikologis, konsumsi obat - obatan tertentu, nutrisi, kondisi lingkungan, serta motivasi ketika istirahat.

Berdasarkan hasil penelitian ini dapat disimpulkan bahwa pola istirahat tidak berhubungan dengan produksi ASI pada ibu nifas. 
Jurnal Kebidanan Harapan Ibu Pekalongan

\section{Kesimpulan}

Penelitian hubungan antara frekuensi makan dan pola istirahat dengan produksi ASI pada ibu nifas di desa Sambung, Grobogan dapat disimpulkan bahwa tidak ada hubungan antara frekuensi makan dengan produksi ASI dimana nilai $\mathrm{p}$ value $=0,092$, sedangkan pada pola istirahat dengan Tidak ada hubungan antara pola instirahat dengan produksi ASI.

Upaya untuk meningkatkan produksi ASI dapat dilakukan dengan mengkonsumsi aneka ragam makanan yang mengandung gizi seimbang yang diperlukan selama menyusui. Penelitian selanjutnya dapat dilakukan dengan menilai kandungan gizi serta kualitas istirahat dari responden

\section{Daftar Pustaka}

[1] Bahiyatun. Buku Ajar Asuhan Kebidanan Nifas Normal. Ester M, editor. Jakarta: EGC, 2009.

[2] Kementerian Kesehatan RI. Profil Kesehatan Indonesia 2015. Jakarta, 2016.

[3] Kementrian Kesehatan RI. Profil Kesehatan Indonesia Tahun 2018. Jakarta: Kementerian Kesehatan RI; 2019.

[4] Rahmawati MD. FaktorFaktor Yang Mempengaruhi Pemberian Asi. Faktor Yang Mempengaruhi Pemberian ASI Ekslusif Pada Ibu Menyusui.;1(1):11, 2010.

[5] Satino, Setyorini Y. Analisis faktor yang mempengaruhi pemberian ASI eksklusif pada ibu primipara di Kota Surakarta. J Terpadu Ilmu Kesehat.;3(2). pp.106-214, 2014.
[6] Ipuk Dwiana Murwanti. Beberapa Faktor yang Mempengaruhi Praktek Pemberian ASI Ekslusif pada Bayi Umur 0-4 Bulan di Desa Paremono Kecamatan Mungkid Kabupaten Magelang. Universitas Diponegoro, 2015. [Online]. http://www.fkm.undip.ac.id.

[7] Mufdillah, Subijanto, Sutisna E\&, Akhyar M. Buku Pedoman Pemberdayaan Ibu Menyusui pada Program ASI Ekslusif. Yogjakarta, 2017.

[8] Sari TD. Faktor-faktor Yang Berhubungan Dengan Produksi Air Susu Ibu (ASI) Eksklusif Pada Ibu Menyusui Di Wilayah Kerja Puskesmas Plus Mandiangin Kota Bukittinggi Tahun 2018. Sekolah Tinggi Ilmu Kesehatan Perintis, 2018.

[9] Sanima. Hubungan pola makan dengan produksi ASI pada ibu menyusui di posyandu mawar kelurahan Tlogomas Kecamatan Lowokwaru Kota Malang. Nurs News J Ilm Keperawatan. ;2(3):154-64, 2017.

[10] Pujiastuti N. Korelasi Antara Status Gizi Ibu Menyusui Dengan Kecukupan Asi Di Posyandu Desa Karang Kedawang Kecamatan Sooko Kabupaten Mojokerto. J Keperawatan.;1(2): 126-37, 2010.

[11] Pranajaya, Rudiyanti N. Determinan Produksi ASI pada Ibu Menyusui. J keperawatan. ;IX(2): 227-37, 2013. 